\title{
The effects of synthetic 19-norprogestins on osteoblastic cell function are mediated by their non-phenolic reduced metabolites
}

\author{
Juana Enríquez, Ana Elena Lemus ${ }^{1}$, Jesús Chimal-Monroy ${ }^{2}$, Higinio Arzate ${ }^{3}$, Gustavo A García ${ }^{4}$, \\ Bertha Herrero $^{5}$, Fernando Larrea and Gregorio Pérez-Palacios ${ }^{6}$ \\ Department of Reproductive Biology, Instituto Nacional de Ciencias Médicas y Nutrición S. Zubirán (INCMNSZ), Mexico City 14000, Mexico \\ ${ }^{1}$ Department of Reproductive Biology, Universidad Autónoma Metropolitana-Iztapalapa, Mexico City 09340, Mexico \\ ${ }^{2}$ Institute of Biomedical Research, ${ }^{3}$ School of Dentistry and ${ }^{4}$ School of Chemistry, Universidad Nacional Autónoma de Mexico (UNAM), Mexico City 04510, \\ Mexico \\ ${ }^{5}$ Department of Nephrology and Mineral Metabolism, INCMNSZ, Mexico City, Mexico \\ ${ }^{6}$ National Institute of Perinatology and School of Medicine, UNAM/Hospital General de México, Montes Urales No. 800, Col. Lomas Virreyes, Mexico, D.F., C.P. \\ 11000, Mexico City, Mexico \\ (Requests for offprints should be addressed to G Pérez-Palacios; Email: gperezpal@prodigy.net.mx)
}

\begin{abstract}
The key role of estrogens on osteoblastic cell function is well documented; however, the role of progesterone $(\mathrm{P})$ and synthetic progestins remains controversial. While several reports indicate that $\mathrm{P}$ has no significant effects on bone cells, a number of clinical studies have shown that 19-norprogestins restore postmenopausal bone loss. The mechanisms by which 19-norprogestins induce estrogenlike effects on bone cells are not fully understood. To assess whether the actions of 19-norprogestins on osteoblasts are mediated by their non-phenolic metabolites, we studied the effects of norethisterone (NET), levonorgestrel (LNG), and two of their A-ring reduced derivatives upon cell proliferation and differentiation in neonatal rat osteoblasts. Osteoblast function was assessed by determining cell DNA, cellassociated osteocalcin and calcium content, alkaline phosphatase activity, and mineral deposition. $\mathrm{P}$ failed to induce changes on osteoblasts, while NET and LNG exerted a
\end{abstract}

number of actions. The most striking finding was that the $3 \beta, 5 \alpha-$ and $3 \alpha, 5 \alpha$-tetrahydro derivatives of NET and LNG induced osteoblast proliferation and differentiation with higher potency than those exerted by their parent compounds, mimicking the effects of estradiol. Interestingly, osteoblast differentiation and mineral deposition induced by NET and LNG were abolished by finasteride, a $5 \alpha$-reductases inhibitor, while the potent effect on osteoblast proliferation induced by progestin derivatives was abolished by a steroidal antiestrogen. Results demonstrate that A-ring reduced derivatives of NET and LNG exhibit intrinsic estrogen-like potency on rat osteoblasts, offering a plausible explanation for the mechanism of action of 19-norprogestins in bone restoration in postmenopausal women and providing new insights for hormone replacement therapy research.

Journal of Endocrinology (2007) 193, 493-504

\section{Introduction}

Estrogens play an essential role in the maintenance of bone mass (Khastgir et al. 2001, Riggs et al. 2002). Indeed, 17ßestradiol $\left(\mathrm{E}_{2}\right)$ enhances osteoblastic cell activity by stimulating proliferation, differentiation, and mineralization in the process of bone formation ( $\mathrm{Qu}$ et al. 1998, Riggs et al. 2002). Even though osteoblastic cells posses the two isoforms of the estrogen-dependent nuclear progesterone receptor (PR) (Rickard et al. 2002), the role of progesterone (P) and synthetic progestins on bone cell function has not been completely elucidated and a number of studies have yielded controversial results. Thus, while several investigators (Scheven et al. 1992, Tremollieres et al. 1992) have demonstrated a stimulatory effect of naturally occurring $\mathrm{P}$ on bone formation, Canalis \& Raisz (1978) have reported that $\mathrm{P}$, at relatively high doses, induces an inhibition of bone formation in cultured rat fetal calvaria. Furthermore, evidence has been presented indicating that $\mathrm{P}$ had very little, if any, effect on bone formation in the ovariectomized rat model (Kalu et al. 1991, Yamamoto et al. 1998). Additionally, clinical studies in postmenopausal women (Riis et al. 1987) have also demonstrated an absence of effect of $\mathrm{P}$ on bone loss.

A series of clinical trials has revealed that synthetic progestins may or may not preserve bone mass, depending on their molecular structure. Several reports have associated the longterm use of the contraceptive progestin depot medroxyprogesterone acetate, a synthetic 17-hydroxyprogesterone derivative, 
with significant bone loss in women in reproductive age (Costa Paiva et al. 1998, Scholes et al. 2002). In addition, Gallagher et al. (1991) have demonstrated that medroxyprogesterone acetate therapy induces a decrease in bone density in postmenopausal women, when compared with estrogens. In contrast, administration of 19-norprogestins induces beneficial effects on bone turnover. Indeed, a number of clinical studies (Abdalla et al. 1985, Christiansen \& Riis 1990, Horowitz et al. 1993) have shown that administration of norethisterone (NET), a synthetic 19-norprogestin, prevents bone mineral loss and reduces bone resorption in postmenopausal women, and also prevents bone loss in young women treated with luteinizing hormonereleasing hormone agonists (Riis et al. 1990). In addition, low-dose subdermal administration of levonorgestrel (LNG), another synthetic 19-norprogestin, also induces an increase in bone mineral density in premenopausal women (Di et al. 1999). Furthermore, clinical and experimental studies have demonstrated that nandrolone decanoate, a synthetic 19-nor anabolic agent, increases bone mass and inhibits bone turnover (Passeri et al. 1993, Li et al. 2000).

The mechanisms of estrogen-like bone actions of 19-norprogestins are not fully understood, particularly since these synthetic steroid molecules neither interact with estrogen receptors (ER; Chávez et al. 1985, Santillán et al. 2001) nor undergo enzyme-mediated aromatization (Gual et al. 1962). An early study conducted in postmenopausal women and castrated patients with complete androgen resistance strongly suggested that the antigonadotropic effect of NET is mediated through the ER, while the effect of medroxy-progesterone acetate (MPA) is mediated through the androgen receptor (Pérez-Palacios et al. 1981). Studies from our laboratory have demonstrated that synthetic 19-norprogestins are extensively bioconverted in target organs to A-ring reduced tetrahydro derivatives (Larrea et al. 1987, Lemus et al. 1992) which exert estrogen-like effects (Vilchis et al. 1986, Moralí et al. 1990, Santillán et al. 2001). Furthermore, recent studies have demonstrated that the protecting neurotoxic effects of progestins are mediated by their $3 \alpha$ - and $3 \beta$-tetrahydro reduced metabolites (Ghoumari et al. 2003, Rhodes et al. 2004, Ciriza et al. 2006).

To assess whether the actions of synthetic 19-norprogestins on bone cell function are mediated by their non-phenolic reduced metabolites, we have studied the effects of NET, LNG, and their $3 \alpha, 5 \alpha-$ and $3 \beta, 5 \alpha$-reduced derivatives on cell proliferation, differentiation, and mineral deposition in cultured osteoblastic cells of neonatal rats. The effects induced by the 19-norprogestins and their tetrahydro reduced derivatives on rat osteoblasts were assessed by determining the cell DNA, cell-associated osteocalcin (OC) and calcium content, alkaline phosphatase (AP) activity, and mineral deposition. Naturally occurring $\mathrm{P}$ and $\mathrm{E}_{2}$ served as the experimental controls. Parallel experiments were carried out in the presence of finasteride, a $5 \alpha$-steroid reductases inhibitor, or in the presence of ICI 182780 , a steroidal antiestrogen.

\section{Materials and Methods}

\section{Materials}

Fetal bovine serum (FBS) was purchased from Hyclone Laboratories, Inc. (Logan, UT, USA), phenol red-free Dulbecco's modified Eagle medium (DMEM) from Life Technologies, and Dulbecco's regular and $\mathrm{Mg}^{+{ }_{-}}$and $\mathrm{Ca}^{++}$-free PBS solutions from Invitrogen Co. Type II collagenase, $\mathrm{E}_{2}$, P, Alizarin red-S, and salmon thymus DNA were purchased from Sigma Chemical Co. Mouse monoclonal bovine carboxylated $\mathrm{OC}$ antibody and peroxidase-labeled rabbit anti-mouse IgG were purchased from Zymed Laboratories, Inc. (San Francisco, CA, USA). Authentic NET (17 $\alpha$-ethynyl-17 $\beta$ hydroxy-19-Nor-4-androsten-3-one) and LNG (17 $\alpha$-ethynyl18-methyl-17 $\beta$-hydroxy-19-Nor-4-androsten-3-one) were kindly provided by Schering Mexicana, SA de CV (Mexico City, Mexico) and Schering AG (Berlin, Germany) respectively. Synthesis of the $3 \beta, 5 \alpha$-tetrahydro derivatives of NET and LNG (3 $\beta, 5 \alpha-N E T, \quad(17 \alpha$-ethynyl-19-Nor-5 $\alpha$-androstan-3 $\beta, 17 \beta-$ diol); $3 \beta, 5 \alpha$-LNG, (17 $\alpha$-ethynyl-18-methyl-19-Nor-5 $\alpha$ androstan-3 $\beta, 17 \beta$-diol) $)$ and their $3 \alpha$ isomers $(3 \alpha, 5 \alpha-\mathrm{NET}$, (17 $\alpha$-ethynyl-19-Nor-5 $\alpha$-androstan-3 $\alpha, 17 \beta$-diol); $3 \alpha, 5 \alpha$ LNG, (17 $\alpha$-ethynyl-18-methyl-19-Nor-5 $\alpha$-androstan$3 \alpha, 17 \beta$-diol)) was done in our laboratories and their physical and spectroscopic constants have been previously described (Chávez et al. 1985, Lemus et al. 1992). Finasteride was provided by Merck Sharp and Dhome de Mexico, SA de CV, while the antiestrogen ICI 182780 was generously supplied by Zeneca Farma (Mexico City, Mexico). All other reagents and solvents used were of analytical grade.

\section{Animals}

Animals used in this study were female Wistar rats born in our laboratory. Rats were killed by decapitation and calvariae were immediately removed. All procedures were performed in accordance with the Guidelines on the Handling and Training of Laboratory Animals published by the Universities Federation for Animal Welfare and approved by the Research Ethics Board of the Instituto Nacional de Ciencias Médicas y Nutrición S. Zubirán.

\section{Isolation and culture of rat osteoblastic cells}

Osteoblastic calvarial cells from 1-day old rats were used throughout the study. Calvariae were carefully dissected, cleaned, and sequentially digested for $60 \mathrm{~min}$ with $0 \cdot 3 \%$ type II collagenase. Cells obtained in the first treatment were discarded, while cells isolated from the subsequent three digestions were pooled, plated, and cultured overnight in flasks with DMEM supplemented with 10\% FBS and $100 \mu \mathrm{M}$ nonessential amino acids and an antibiotic-antimycotic solution $(100 \mathrm{U} / \mathrm{ml}$ penicillin, $100 \mu \mathrm{g} / \mathrm{ml}$ streptomycin, and $250 \mathrm{ng} / \mathrm{ml}$ amphotericin-B; Gibco BRL) at $37^{\circ} \mathrm{C}$, in a humidified atmosphere of $5 \% \mathrm{CO}_{2}$ in air. 

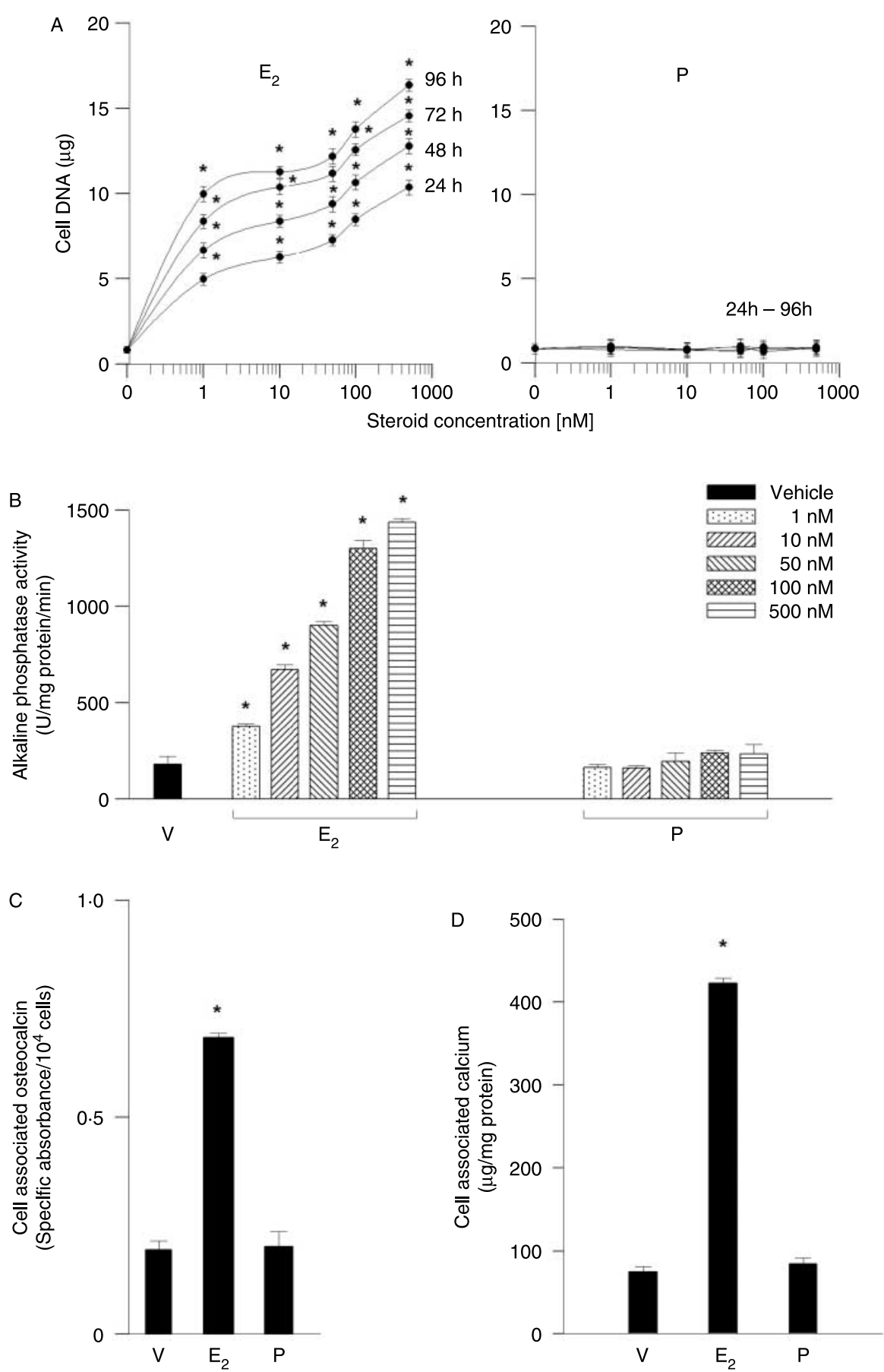

Figure 1 Effects of naturally occurring estradiol $\left(E_{2}\right)$ and progesterone $(P)$ on cell proliferation, differentiation, and mineralization in cultured neonatal rat osteoblasts. (A) Effect of increasing concentrations of $\mathrm{E}_{2}$ and $\mathrm{P}$ on osteoblasts DNA content. Osteoblasts DNA content in the absence of steroids (vehicle alone) was $0 \cdot 85 \pm 0 \cdot 32 \mu \mathrm{g}$, at all incubation time periods. (B) Effect of varying concentrations of $E_{2}$ and $P$ on osteoblastic cells alkaline phosphatase activity (U/mg protein per min) after incubations for 15 days. (C and D) Effect of a single dose $(50 \mathrm{nM})$ of $E_{2}$ and Pon cell-associated osteocalcin (specific absorbance $/ 10^{4}$ cells) and cell-associated calcium content ( $\mu \mathrm{g} / \mathrm{mg}$ protein), after incubations for 15 consecutive days. Results represent the mean \pm s.D. of three experiments in sixtuplicate each. $* P<$ 0.0001 when compared with vehicle (V) control incubations. For details refer text. 
Assessment of the phenotype of cultured rat calvarial cells was done by determining the presence of OC and AP activity, according to the methods described by Kaplow (1955) and Arzate et al. (1998) respectively. The results revealed the presence of these two bone-related proteins in more than $95 \%$ of the calvarial cells, thus demonstrating the distinctive features of the osteoblast phenotype. At confluence, primary rat osteoblasts were detached with $0 \cdot 25 \%$ trypsin $/ 1 \mathrm{mM}$ EDTA, counted, and submitted to different experimental studies.

\section{Cell proliferation studies}

To assess the effects of 19-norprogestins and their derivatives on bone cell proliferation, increasing concentrations $(1-500 \mathrm{nM})$ of NET, LNG, $3 \alpha, 5 \alpha-\mathrm{NET}, 3 \beta, 5 \alpha-\mathrm{NET}$, $3 \alpha, 5 \alpha-\mathrm{LNG}$, and $3 \beta, 5 \alpha-\mathrm{LNG}$, dissolved in propylene glycol, used as vehicle, were incubated for 4 days with cultured osteoblasts. Identical concentrations of $\mathrm{E}_{2}$ and $\mathrm{P}$, and vehicle were used as controls. Osteoblasts were plated at $2 \times 10^{4}$ cells/well in culture medium (DMEM containing 5\% stripped FBS treated with charcoal-dextran, nonessential amino acids, antibiotics, and antimycotic), allowing adherence for $6 \mathrm{~h}$. To preclude base line cell proliferation, the medium was removed and replaced by DMEM containing $0 \cdot 5 \%$ stripped FBS, $5 \mu \mathrm{g} / \mathrm{ml}$ ascorbic acid, amino acids, antibiotics, and antimycotic (incubation medium), and incubated for additional $6 \mathrm{~h}$. Osteoblasts were then incubated for four consecutive days in incubation medium with natural and synthetic steroids added. The medium was removed daily and replaced by fresh incubation medium containing identical steroid concentrations.

Cell proliferation was assessed by the daily determination of DNA content in both steroid-stimulated and control cultured cells on day 0 through day 4. DNA was measured using the method of Labarca \& Paigen (1980), using purified salmon
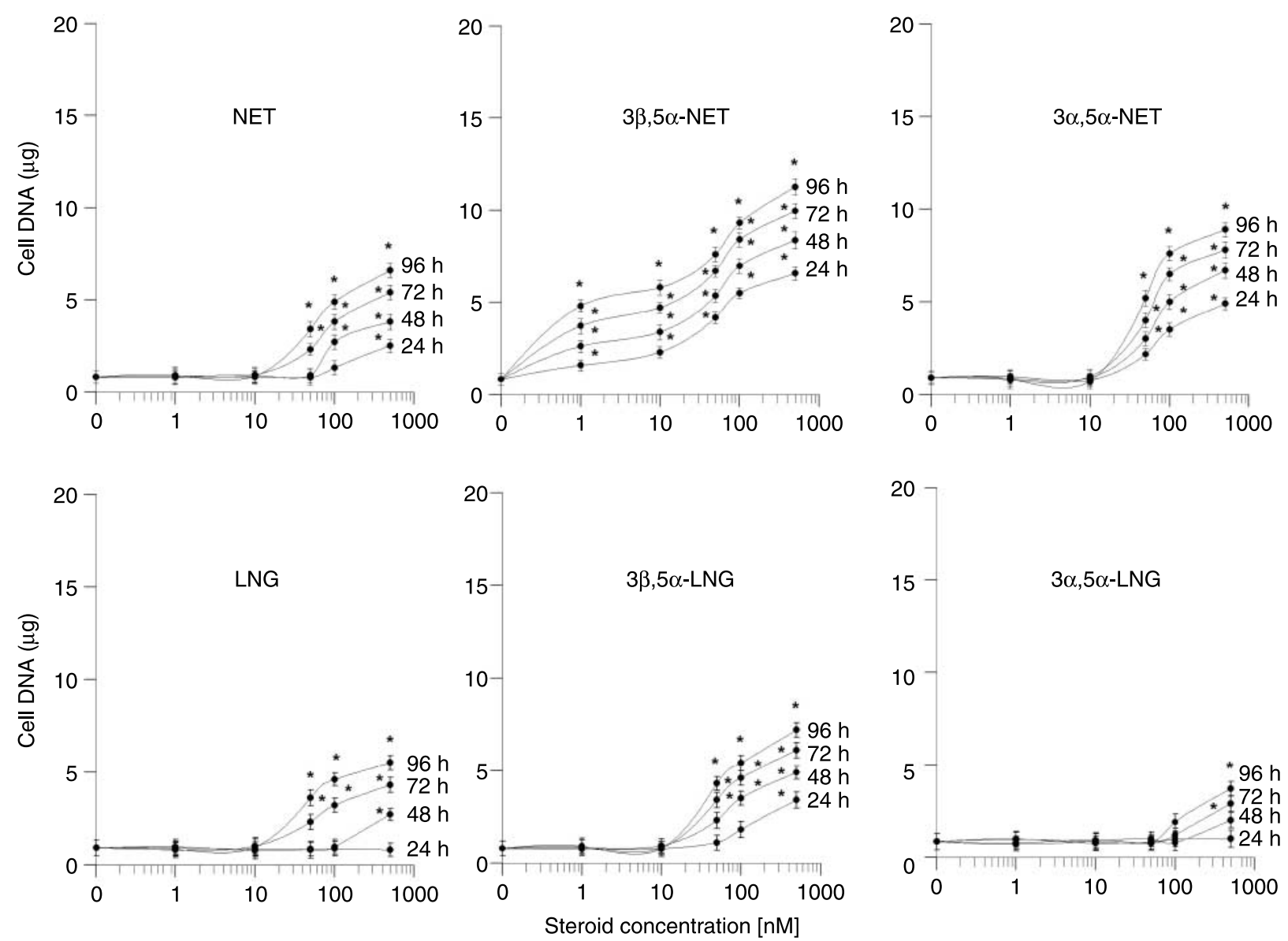

Figure 2 Effect of two synthetic 19-norprogestins and their A-ring reduced derivatives on DNA cell content of cultured rat calvarial

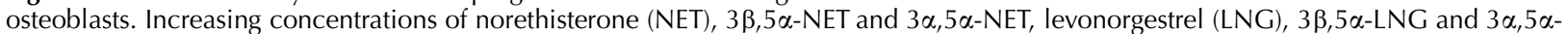
LNG, were incubated with osteoblastic cells for 4 consecutive days. Cell DNA was determined at 0, 24, 48, 72, and 96 h of steroid stimulation. Values represent the mean \pm s.D. of three experiments in sixtuplicate each. ${ }^{*} P<0 \cdot 0001$ when compared with vehicle control incubations. 
thymus DNA as standard, and the results were expressed as micrograms of DNA. Additional experiments using the tetrahydro derivatives of NET and LNG were carried out in the presence of ICI 182780 , using $\mathrm{E}_{2}$ and vehicle as controls. The DNA content in steroid-stimulated and control cultured cells was assessed after $24 \mathrm{~h}$ of treatments.

\section{Cell differentiation studies}

To evaluate the effects of synthetic progestins and their reduced derivatives on osteoblast differentiation, two biomarkers of bone formation, AP activity and OC content, were used in cells with and without exposure to steroids. To determine osteoblast AP activity, cells were plated at $20 \times 10^{4}$ cells/well density in culture medium containing $50 \mu \mathrm{g} / \mathrm{ml}$ ascorbic acid and increasing concentrations of NET, LNG, and their A-ring tetrahydro reduced derivatives, using $\mathrm{E}_{2}, \mathrm{P}$, and vehicle as controls (day 0 ). Thereafter, medium was removed every other day and replaced by fresh medium with identical steroid concentrations or vehicle and incubated for 15 days. Additional experiments with NET and LNG were carried out in the presence or absence of finasteride. At the end of the steroid stimulation period, cells were harvested and lysed in a solution containing $0 \cdot 1 \mathrm{M}$ Tris- $\mathrm{HCl}$ and $0 \cdot 1 \%$ Tween 20 , at $\mathrm{pH} 7 \cdot 5$ for $2 \mathrm{~min}$. Cell lysates were freezethawed $(2 \times)$ and submitted to AP activity measurement. AP activity was determined by the method described by Lowry et al. (1954), using $p$-nitrophenyl phosphate as substrate. Protein concentration was determined by Bradford's (1976) dye binding method, using BSA as standard.

To determine the content of osteoblast-associated OC, cells were seeded at $4 \times 10^{4}$ cells/well density in culture medium, containing $50 \mu \mathrm{g} / \mathrm{ml}$ ascorbic acid and $50 \mathrm{nM}$ each of NET, LNG, and their tetrahydro derivatives, using $\mathrm{E}_{2}, \mathrm{P}$, and vehicle as controls. Additional incubations with NET or LNG were done in the presence or absence of $75 \mu \mathrm{M}$ finasteride. Steroid stimulation lasted 15 days, with medium removal and replacement every other day. At the end of steroid stimulation, cells were fixed to the plates using PBS containing $0.05 \%$ glutaraldehyde, at $4{ }^{\circ} \mathrm{C}$, for $30 \mathrm{~min}$. Immediately after, plates were washed and dried, and the cells were incubated for $24 \mathrm{~h}$ with $1 \%$ BSA in $0.2 \mathrm{M}$ carbonate buffer, $\mathrm{pH} 9 \cdot 6$, at $4{ }^{\circ} \mathrm{C}$, in the dark. The osteoblastassociated $\mathrm{OC}$ content in the extracellular matrix was determined by a cell-ELISA method, similar to that developed by Nibbering et al. (1990) for the quantification of proteins localized in the cell surface. Briefly, cells were incubated for $2 \mathrm{~h}$ with mouse monoclonal bovine OC antibody (1:500) in PBS-Tween 20 at $37^{\circ} \mathrm{C}$. After washing the plates $(3 \times)$ with $0.05 \%$ PBS-Tween 20 , cells were incubated for $1 \mathrm{~h}$ with peroxidase-labeled rabbit anti-mouse $\operatorname{IgG}(1: 1000)$ in $0 \cdot 05 \%$ PBS-Tween 20 at $37^{\circ} \mathrm{C}$. Following the removal of anti-IgG excess, cells were incubated at room temperature in the dark for $30 \mathrm{~min}$ with $0.4 \mathrm{mg} / \mathrm{ml}$ o-phenylenediamine (Sigma Chemical Co.) and 30\% hydrogen peroxide in a sodium phosphate-citric acid buffer $(0 \cdot 2 \mathrm{M}$
$\mathrm{Na}_{2} \mathrm{HPO}_{4}$ and $0 \cdot 1 \mathrm{M}$ citric acid). At the end of incubation, $50 \mu \mathrm{l}$ of $2 \mathrm{M} \mathrm{H}_{2} \mathrm{SO}_{4}$ were added. For the calculation of OC content in the extracellular matrix, use was made of the linear part of the curve obtained when the number of cells was plotted against the absorbance values of the peroxidase reaction product at $490 \mathrm{~nm}$.

\section{Cell-associated calcium content and mineral deposition}

To assess the effect of synthetic progestins and their reduced derivatives on osteoblast mineralization, the cell-associated calcium content and mineral deposition were determined. Cells were seeded at $20 \times 10^{4}$ cells/well density in culture medium, additioned with $10 \mathrm{mM} \beta$-glycerophosphate, and incubated with a single dose of NET, LNG, and their $3 \alpha, 5 \alpha-$ and $3 \beta, 5 \alpha$-reduced derivatives, for 15 days, using $\mathrm{E}_{2}$, P, and vehicle as controls. Culture medium was replaced every other day by fresh medium containing identical steroids concentration. At the end of the steroid-stimulation period, cells were submitted for determination of cell-associated calcium content and mineral deposition. Osteoblast-associated calcium content was determined after cells were washed $(3 \times)$ with $\mathrm{Ca}^{++}$and $\mathrm{Mg}^{++}$-free PBS, decalcified overnight with $0.5 \mathrm{M} \mathrm{HCl}$ at $4{ }^{\circ} \mathrm{C}$ and centrifuged $(4000 \mathrm{~g})$ for $5 \mathrm{~min}$ at $4{ }^{\circ} \mathrm{C}$. Cell-associated calcium was quantified in the supernatant using an atomic absorption spectrophotometer PerkinElmer Model 3110 (Norwalk, CT, USA), using pure calcium

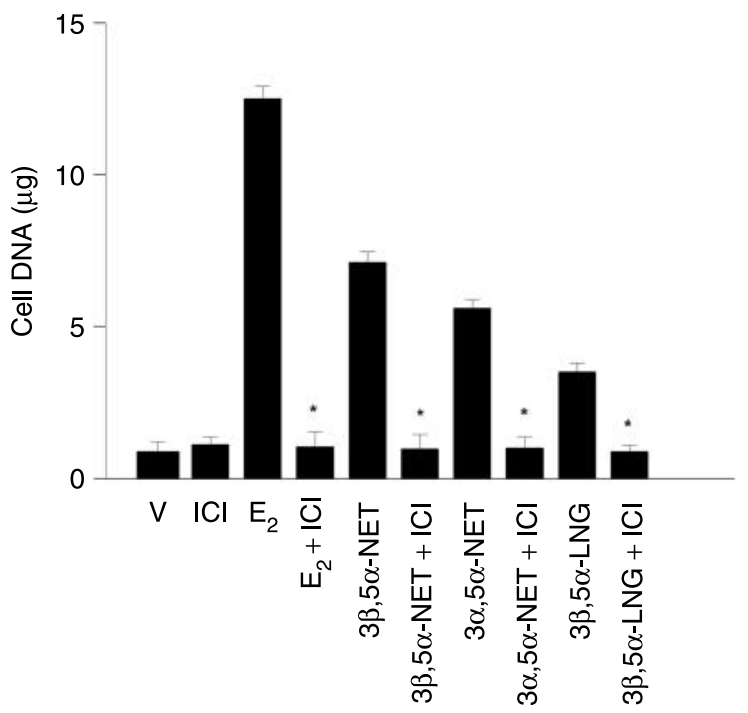

Figure 3 Effect of $\mathrm{ICl} 182780(\mathrm{ICl})$, an estrogen antagonist, on the increase of cell DNA content induced in cultured rat osteoblasts by naturally occurring estradiol $\left(E_{2}\right)$ and the tetrahydro reduced derivatives of norethisterone (NET) and levonorgestrel (LNG). Osteoblastic cells were incubated with $500 \mathrm{nM}$ each of the following steroids: $E_{2}, 3 \beta, 5 \alpha-N E T, 3 \alpha, 5 \alpha-N E T$, and $3 \beta, 5 \alpha-L N G$, in the presence or absence of $250 \mu \mathrm{M} \mathrm{ICl}$, for $24 \mathrm{~h}$. Results are expressed as micrograms of DNA and the values represent the mean \pm s.D. of three experiments in sixtuplicate each. ${ }^{*} P<0 \cdot 0001$ when compared with incubations in the absence of the antiestrogen. 

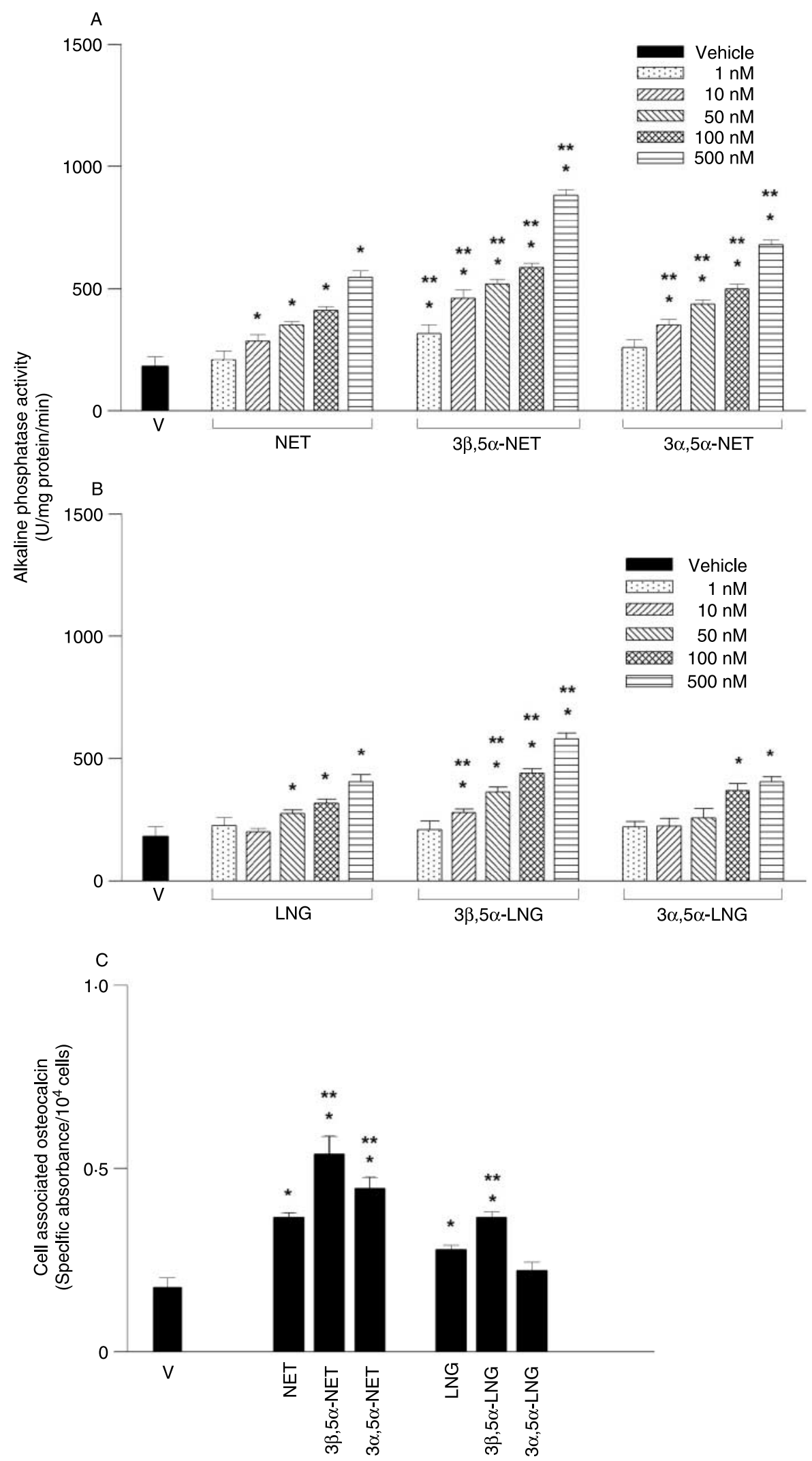
as atomic spectroscopy standard (Perkin-Elmer Instruments, Shelton, CT, USA).

Osteoblast mineral deposition was evaluated after cells were fixed to plates with neutral formalin and incubated at room temperature for $15 \mathrm{~min}$ in a saturated Alizarin red-S solution in PBS, $\mathrm{pH} 4 \cdot 1$. Plates were rinsed $(3 \times)$ in tap water, dried, and submitted for mineral deposition observation, using a Nikon stereoscopic microscope, Model SMZ 1500, and photographed with a digital Nikon E995 camera (Nikon Inc., Melville, NY, USA). An integrated density analysis in representative samples was done using a still video system Stratagene Model Eagle Eye II (La Jolla, CA, USA). Results are given as integrated density numerical values (pixels) obtained by the use of a Lab Works 4.5 software (UVP Bioimagen Systems, Upland, CA, USA). An identical set of experiments aimed to evaluate mineral deposition in cultured cells stimulated with NET and LNG was done in the presence of finasteride.

\section{Statistical analysis}

Comparisons of experimental groups with controls were done by one-way ANOVA. Statistical differences between groups were established by Student's $t$-test (SigmaStat Statistical Analysis System, Jandel Corporation, San Rafael, CA, USA). Group differences were considered significant when $P \leq 0 \cdot 05$ was reached (two-tailed test; Montgomery 1991).

\section{Results}

The effects of naturally occurring sex steroid hormones on neonatal rat osteoblasts proliferation, differentiation, and mineralization are shown in Fig. 1. Addition of increasing concentrations of $\mathrm{E}_{2}$ to cultured osteoblasts resulted in a significant, dose- and time-dependent increase $(P<0 \cdot 0001)$ in cell DNA content (Fig. 1A), even at the lower dose employed $(1 \mathrm{nM})$, when compared with the vehicle alone. In contrast, addition of $\mathrm{P}$ to osteoblast cultures, even at the higher dose employed $(500 \mathrm{nM})$, completely failed to induce changes in cell DNA content. Incubations of osteoblasts with varying concentrations of $\mathrm{E}_{2}$ resulted in a significant, dosedependent increase $(P<0.0001)$ in AP activity, when compared with the vehicle (Fig. 1B), while $\mathrm{P}$ was unable to induce an increase in cell enzyme activity. Stimulation of osteoblasts with $E_{2}(50 \mathrm{nM})$ induced a significant increase $(P<0 \cdot 0001)$ in cell-associated OC content, when compared with the vehicle alone, whereas a similar dose of $\mathrm{P}$ did not induce changes in the osteoblast OC content (Fig. 1C). Addition of $\mathrm{E}_{2}$ to cultured osteoblasts resulted in a significant increase $(P<0.0001)$ in cell-associated calcium content, when compared with the vehicle (Fig. 1D), while P completely failed to induce changes in the cell content of calcium.

The effect of NET, LNG, and their non-phenolic reduced derivatives on osteoblast proliferation is depicted in Fig. 2. Addition of NET to cultured neonatal rat osteoblasts induced a significant effect $(P<0 \cdot 0001)$ on cell DNA content, noticeable only at $50 \mathrm{nM}$ dose and above, particularly after long incubation periods (Fig. 2). NET at low doses (1 and $10 \mathrm{nM}$ ) was ineffective to induce significant changes in cell proliferation at all stimulation time periods. On the contrary, incubations of neonatal rat osteoblasts with increasing concentrations of $3 \beta, 5 \alpha-\mathrm{NET}$ resulted in a significant, dose-dependent increase $(P<0.0001)$ in cell DNA content, even at the lower dose employed $(1 \mathrm{nM})$, at all stimulation time periods, resembling the effect of naturally occurring $E_{2}$ (Fig. 1A), though with lower potency. The $3 \alpha, 5 \alpha-\mathrm{NET}$ derivative also induced an increase in the DNA content of cultured osteoblasts, yet with less effectiveness than its $3 \beta$ epimer. Low doses of $3 \alpha, 5 \alpha$-NET $(1$ and $10 \mathrm{nM})$ were ineffective; however, at $50 \mathrm{nM}$ dose and above, an increase in cell DNA was noticed at all stimulation time periods.

The synthetic progestin LNG also induced an increase in osteoblasts DNA content, though weaker than that observed with NET. The effect of LNG on osteoblast proliferation was noticed at high doses, after long-term stimulation periods (Fig. 2). The effect of the $3 \beta, 5 \alpha$-tetrahydro derivative of LNG in neonatal rat osteoblasts was more potent than that exhibited by LNG, but weaker than that of the corresponding $3 \beta, 5 \alpha$ derivative of NET. Indeed, $3 \beta, 5 \alpha-\mathrm{LNG}$ at high doses $(500 \mathrm{nM})$ was able to induce a cell DNA increase, since the first $24 \mathrm{~h}$ of stimulation. In contrast, $3 \alpha, 5 \alpha-\mathrm{LNG}$ induced very little, if any, increase in osteoblasts DNA content (Fig. 2). The rank order of potency of natural and synthetic steroids to stimulate osteoblast proliferation was: estradiol $>3 \beta, 5 \alpha-$ $\mathrm{NET}>3 \alpha, 5 \alpha-\mathrm{NET}>3 \beta, 5 \alpha-\mathrm{LNG}>\mathrm{NET}>\mathrm{LNG}>3 \alpha, 5 \alpha-$ LNG. Incubations of osteoblasts with the tetrahydro NET and LNG derivatives in the presence of ICI 182780 resulted in a complete inhibition $(P<0 \cdot 0001)$ of osteoblast proliferation induced by the synthetic progestins derivatives as depicted in Fig. 3. A similar effect of the antiestrogen on $\mathrm{E}_{2}$-induced cell proliferation was noticed.

The effect of increasing concentrations of NET, LNG, and their reduced derivatives on AP activity of cultured neonatal rat osteoblasts is shown in Fig. 4A and B. Addition of NET at

Figure 4 Effect of norethisterone (NET), levonorgestrel (LNG), and their tetrahydro reduced derivatives on neonatal rat osteoblast differentiation. Alkaline phosphatase activity was determined in osteoblastic cells incubated with increasing concentrations (1-500 $\mathrm{nM}$ ) of (A) NET, $3 \beta, 5 \alpha-N E T$ and $3 \alpha, 5 \alpha-N E T$, and (B) LNG, $3 \beta, 5 \alpha-L N G$ and $3 \alpha, 5 \alpha-L N G$, for 15 consecutive days. Steroids were dissolved in propylene glycol, used as vehicle (V). The cell enzyme activity is expressed as $\mathrm{U} / \mathrm{mg}$ protein per min. (C) The effect of 19-norprogestins and their derivatives on the cell-associated osteocalcin content (specific absorbance $/ 10^{4}$ cells) was assessed after incubations with a single dose $(50 \mathrm{nM})$ of each steroid for 15 consecutive days. Results represent the mean \pm s.D. of three experiments in sixtuplicate each. ${ }^{*} P<0 \cdot 0001$ compared with vehicle, ${ }^{* *} P<0 \cdot 0001$ compared with the corresponding parent progestin. 
$10 \mathrm{nM}$ dose and above to cultured osteoblasts resulted in a significant increase $(P<0.0001)$ in AP activity, when compared with vehicle alone (Fig. 4A). $3 \beta, 5 \alpha-N E T$ induced a significant, dose-dependent increase $(P<0.0001)$ in osteoblast AP activity, even at the lower dose employed $(1 \mathrm{nM})$, in a similar manner to that observed with $\mathrm{E}_{2}$ (Fig. 1B), though with lower potency. Addition of $3 \alpha, 5 \alpha-$ NET also induced a significant, dose-dependent increase in osteoblast AP activity, yet with lower potency than its $3 \beta$ epimer (Fig. 4A). The synthetic progestin LNG induced a weak, though significant, effect $(P<0 \cdot 0001)$ on osteoblast AP activity, noticeable only at $50 \mathrm{nM}$ dose and above (Fig. 4B). $3 \beta, 5 \alpha$-LNG induced a significant, dose-dependent increase $(P<0.0001)$ in osteoblast AP activity as $10 \mathrm{nM}$ dose is more potent than unmodified LNG, but less potent than $E_{2}$ (Fig. 1B). The $3 \alpha, 5 \alpha$-LNG derivative exhibited a very weak effect on osteoblasts AP activity, noticed only at higher doses $(100$ and $500 \mathrm{nM})$. The rank order of potency of steroids to induce enhancement in AP activity in cultured rat osteoblastic cells was: $\mathrm{E}_{2}>3 \beta, 5 \alpha-\mathrm{NET}>3 \alpha, 5 \alpha-\mathrm{NET}>3 \beta, 5 \alpha-\mathrm{LNG}>$ NET $>$ LNG $>3 \alpha, 5 \alpha-$ LNG.

The effect of NET, LNG, and their derivatives on cellassociated OC content in cultured neonatal rat osteoblasts is depicted in Fig. 4C. Stimulation of cultured osteoblasts with NET and its A-ring reduced derivatives resulted in a significant increase $(P<0 \cdot 0001)$ in cell OC content when compared with the vehicle alone, resembling the effect induced with $\mathrm{E}_{2}$ (Fig. 1C), though with a slightly lower potency. $3 \beta, 5 \alpha-\mathrm{NET}$ was the most effective inductor of cellassociated OC increase, exhibiting a higher potency than those of its $3 \alpha$ epimer and unmodified NET. Incubations of cultured osteoblasts with LNG and its A-ring reduced derivatives yielded different results. As shown in Fig. 4C, unmodified LNG had a significant effect on osteoblasts OC content, though with lower potency than NET. $3 \beta, 5 \alpha-\mathrm{LNG}$ induced an increase in cell OC content with higher potency than that of LNG, while $3 \alpha, 5 \alpha-\mathrm{LNG}$ was ineffective.

The effect of finasteride on the progestins-induced increase of AP activity in cultured osteoblasts is depicted in Fig. 5A. Experiments were designed to inhibit both $5 \alpha$-steroid reductases; therefore, high doses of the inhibitor were used. Studies on human breast cancer cells (Pérez-Palacios et al. 2006) and cultured rat osteoblasts (unpublished) in our laboratory have shown that finasteride, at this dose level, specifically inhibits types 1 and 2 of $5 \alpha$-reductases. Incubations of osteoblasts with NET or LNG, in the presence of finasteride, resulted in a complete inhibition $(P<0 \cdot 0001)$ of the progestins-induced increase of cell AP activity. The results of incubations of cultured osteoblasts with NET or LNG on cell-associated OC content, in the presence or absence of finasteride, are shown in Fig. 5B. Finasteride was able to induce a complete inhibition $(P<0 \cdot 0001)$ of the NET and LNG-induced increase of the osteoblast content of OC.

The effect of synthetic progestins and their derivatives on osteoblast-associated calcium content is shown in Fig. 6. Stimulation of cultured osteoblasts with NET resulted in a significant increase $(P<0 \cdot 0001)$ in cell calcium content when compared with vehicle, whereas $3 \beta, 5 \alpha$ - and $3 \alpha, 5 \alpha-\mathrm{NET}$ exhibited a higher potency than that observed with unmodified NET. Stimulation of cultured osteoblasts with
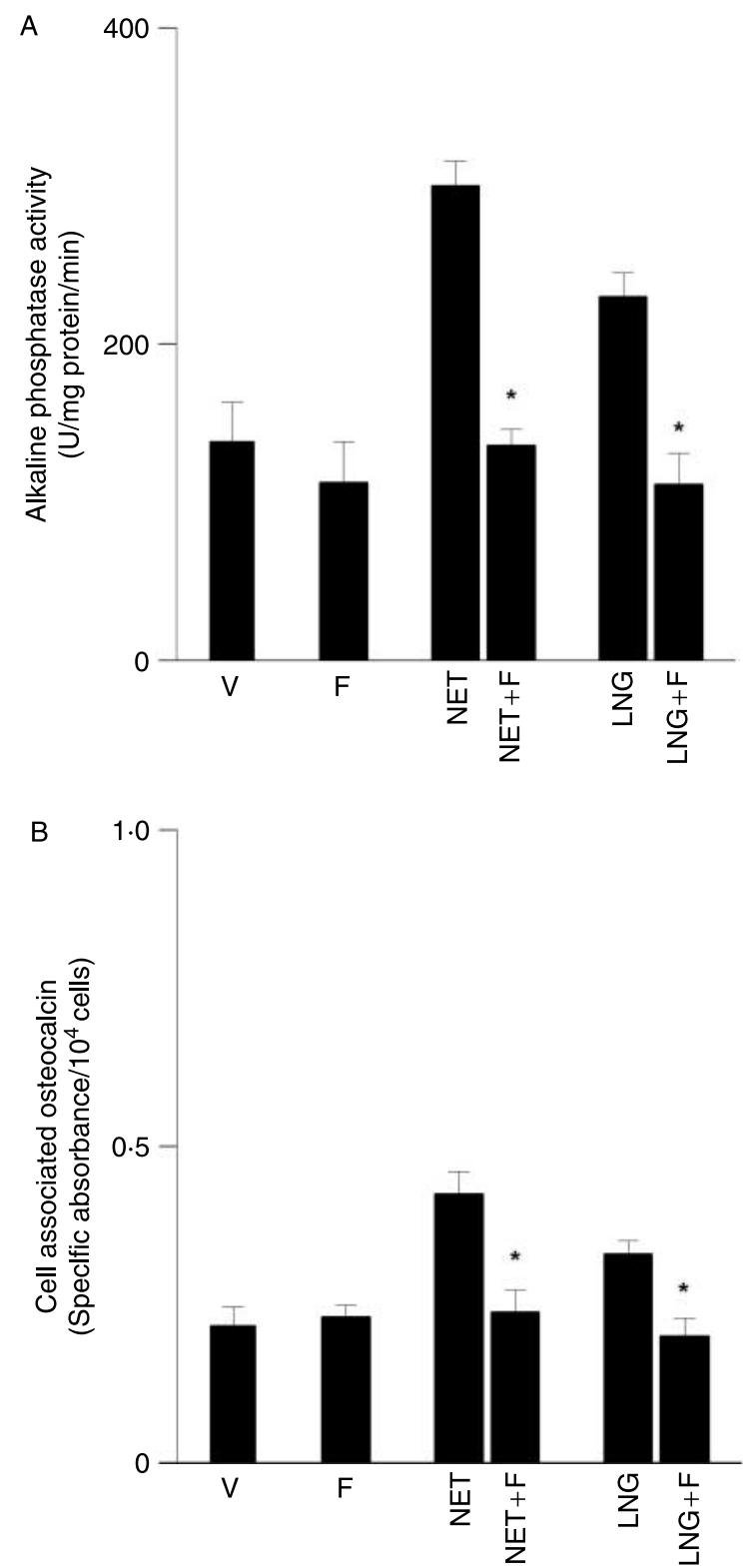

Figure 5 Effect of finasteride $(\mathrm{F})$, a $5 \alpha$-steroid reductases inhibitor, on (A) the increase of alkaline phosphatase activity and (B) cellassociated osteocalcin content in neonatal rat osteoblasts, induced by two synthetic 19-norprogestins. Osteoblastic cells were incubated with $50 \mathrm{nM}$ norethisterone (NET) or levonorgestrel (LNG), in the presence or absence of $75 \mu \mathrm{M} \mathrm{F}$, for 15 consecutive days. Results are expressed as alkaline phosphatase activity $(\mathrm{U} / \mathrm{mg}$ protein per $\mathrm{min}$ ) and cell-associated osteocalcin (specific absorbance $/ 10^{4}$ cells), and the values represent the mean \pm s.D. of three experiments in sixtuplicate each. $* P<0 \cdot 0001$ when compared with incubations in the absence of finasteride. 


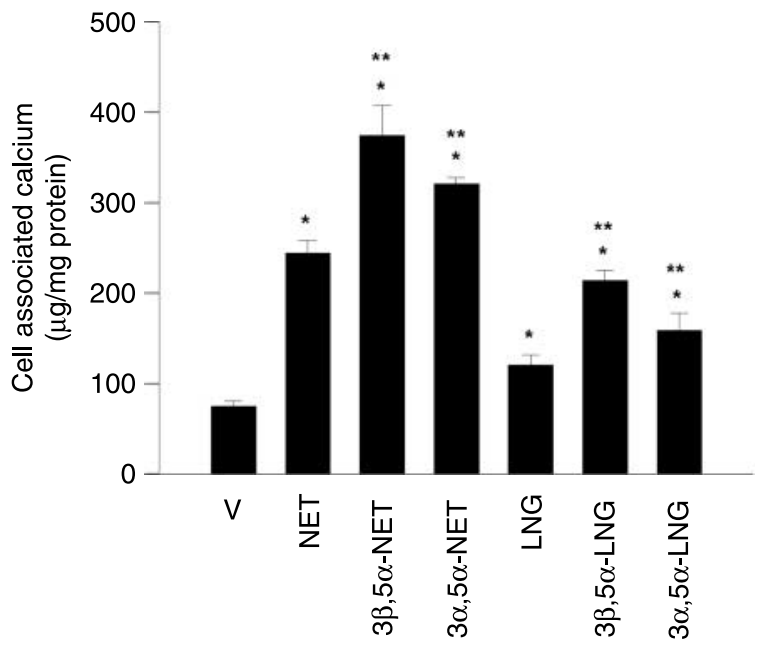

Figure 6 Osteoblastic cell mineralization induced by two 19-norprogestins and their A-ring reduced derivatives, as assessed by the cell-associated calcium content. Neonatal rat osteoblasts were incubated with $50 \mathrm{nM}$ norethisterone (NET) and levonorgestrel (LNG), $3 \beta, 5 \alpha$-NET, $3 \alpha, 5 \alpha$-NET, $3 \beta, 5 \alpha$-LNG or $3 \alpha, 5 \alpha$-LNG, for 15 consecutive days, using vehicle (V) as control. Results are expressed as $\mu \mathrm{g}$ calcium $/ \mathrm{mg}$ protein and the values represent the mean \pm s.D. of three experiments in sixtuplicate each. $* P<0.0001$ when compared with vehicle, ${ }^{* *} P<0.0001$ when compared with the corresponding parent progestin.

LNG and its derivatives also induced a significant increase in cell calcium content, in a similar manner to that observed with NET and its derivatives, though with lower potency (Fig. 6).

Figure 7 shows the mineral deposition in osteoblast cultures stimulated with NET, LNG, and their tetrahydro reduced derivatives, as stained with Alizarin red-S. $E_{2}$, P, vehicle, and finasteride alone were used as controls. Naturally occurring $\mathrm{E}_{2}$ induced a large mineral deposition $\left(406 \times 10^{3}\right.$ pixels $)$, while $\mathrm{P}$ was ineffective to induce osteoblast mineralization $\left(117 \times 10^{3}\right.$ pixels $)$. Indeed, the image of stained P-stimulated osteoblasts was similar to that observed in vehicle-treated cells $\left(110 \times 10^{3}\right.$ pixels $)$. Stimulation of cultured osteoblasts with unmodified NET resulted in a mineral deposition $\left(191 \times 10^{3}\right.$ pixels), with lower density than that induced with $E_{2}$. Interestingly, $3 \beta, 5 \alpha-\mathrm{NET}$ was more potent $\left(289 \times 10^{3}\right.$ pixels $)$ than unmodified NET, mimicking the effect of $E_{2}$, yet with lower potency. The $3 \alpha, 5 \alpha-\mathrm{NET}$ derivative also induced mineral deposition $\left(175 \times 10^{3}\right.$ pixels), though with lower density than that observed after stimulation with $\mathrm{E}_{2}$ or $3 \beta, 5 \alpha-$ NET. The synthetic progestin LNG and its tetrahydro reduced derivatives, particularly $3 \beta, 5 \alpha$-LNG $\left(231 \times 10^{3}\right.$ pixels), were able to induce mineral deposition in cultured osteoblasts, in a similar manner to NET and its corresponding derivatives, though to a lesser extent. Addition of finasteride to incubations of cultured osteoblasts with NET or LNG precluded the progestins-induced mineral deposition as shown in Fig. 7.

\section{Discussion}

The results obtained throughout this study contribute with a plausible explanation to the understanding of the mode of action of synthetic 19-norprogestins in the bone cells. Indeed, using primary cultures of calvarial osteoblasts derived from newborn rats, we were able to show that the significant effects induced by two progestins, NET and LNG, on cell proliferation, differentiation, and mineralization processes are mediated by their A-ring reduced derivatives, mimicking the effects of $E_{2}$. The data also provide evidence that naturally occurring progesterone has no effects at all on osteoblastic cell function. The findings of a complete lack of progesterone effectiveness on osteoblasts function are in line with the observation that a female murine model, carrying a null mutation of the $P R$ gene, has not apparent alterations in peak bone mass or bone histomorphometry, thus demonstrating that PR does not play a direct role in the processes which govern normal bone development (Bain et al. 1997). In contrast, NET and, to a lesser extent, LNG, at high doses (50 $\mathrm{nM}$ and above) after long-term incubation periods, stimulated osteoblasts proliferation in a dose-dependent fashion. The effect of both 19-norprogestins was similar to that observed with $\mathrm{E}_{2}$, yet with significantly lower potency. This observation confirms and extends the demonstration that NET stimulates proliferation of cultured human osteosarcoma cells (Lau et al. 1994).

The most striking finding was that the $3 \beta, 5 \alpha$-tetrahydro reduced derivatives of NET and LNG successfully stimulated osteoblasts proliferation, with higher potency than that of their parent compounds, resembling the effect of $E_{2}$. The $3 \alpha, 5 \alpha$-derivative of NET also induced an increase in osteoblasts proliferation, with lower potency than that of its $3 \beta$ epimer, while $3 \alpha, 5 \alpha$-LNG was almost ineffective. These results strongly suggest that the rat osteoblasts enhancement of cell proliferation induced by the 19-norprogestins are mediated by their tetrahydro reduced derivatives and their further interaction with nuclear ER. Additional support to this concept was derived from the finding that ICI 182780 , a potent steroidal estrogen antagonist, was capable of abolishing the osteoblastic cell proliferation effect induced by both the A-ring reduced derivatives of NET and LNG, and $\mathrm{E}_{2}$.

The two 19-norprogestins and their A-ring reduced derivatives exhibited relevant effects on rat osteoblasts differentiation, as assessed by the changes induced on cell $\mathrm{AP}$ activity and $\mathrm{OC}$ content. It must be underlined that these effects were noticed only after 15 consecutive days of stimulation, in a fashion similar to that observed with $\mathrm{E}_{2}$. This observation correlates well with the findings of Stein et al. (1990) and Qu et al. (1998), who have demonstrated that $\mathrm{E}_{2}$-induced expression of AP mRNA and OC mRNA in rodent osteoblast cultures are not detected before day 12 of stimulation. Interestingly, the enhancing effect on both cell biomarkers, induced by the $3 \beta, 5 \alpha$-reduced derivatives of NET and LNG, was more potent than that observed with 


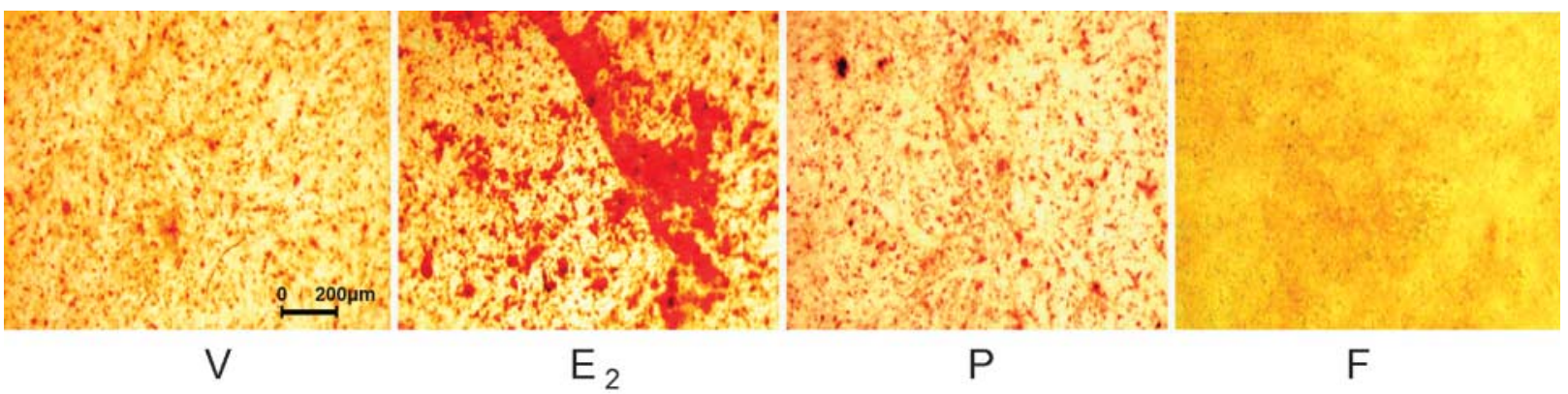

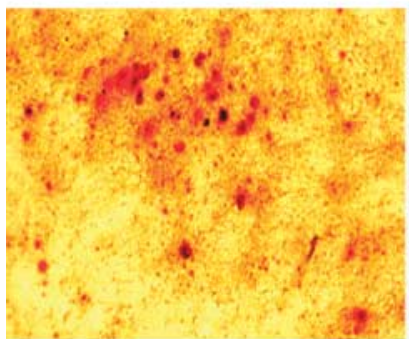

NET

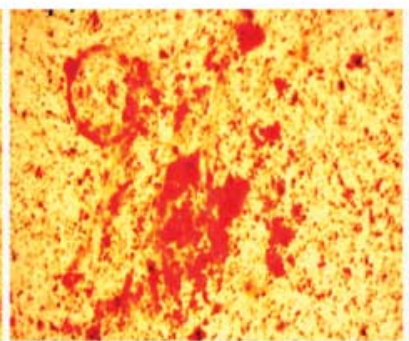

$3 \beta, 5 \alpha-N E T$

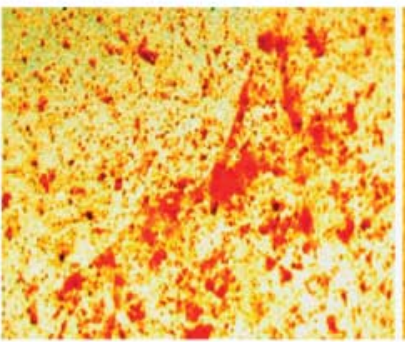

$3 \alpha, 5 \alpha-N E T$

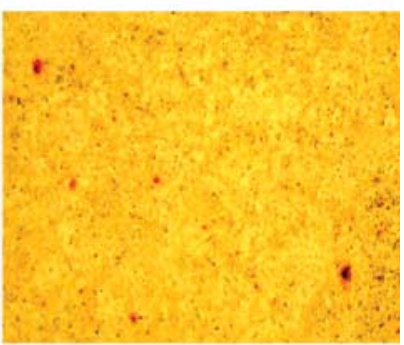

$\mathrm{NET}+\mathrm{F}$

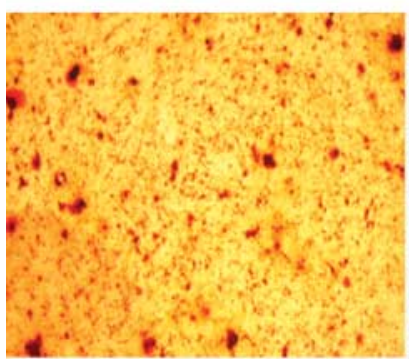

LNG

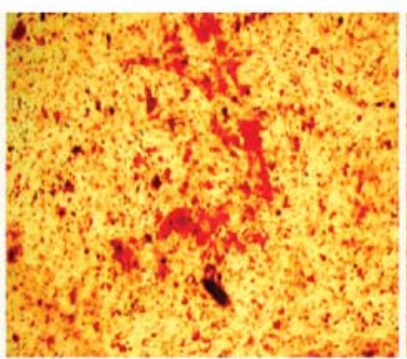

$3 \beta, 5 \alpha-L N G$

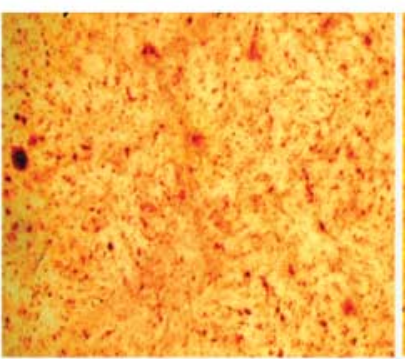

$3 \alpha, 5 \alpha-$ LNG

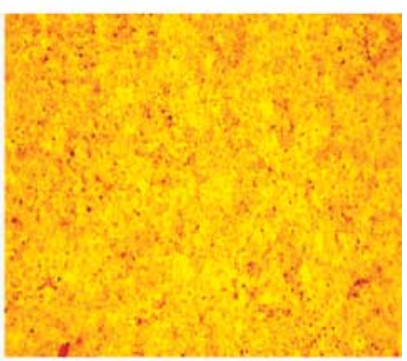

$\mathrm{LNG}+\mathrm{F}$

Figure 7 Mineral deposition in osteoblastic cell cultures induced by estradiol $\left(\mathrm{E}_{2}\right)$, progesterone $(\mathrm{P})$, norethisterone (NET), levonorgestrel (LNG), and their tetrahydro reduced derivatives ( $3 \beta, 5 \alpha-\mathrm{NET}, 3 \alpha, 5 \alpha-\mathrm{NET}, 3 \beta, 5 \alpha-\mathrm{LNG}$, and $3 \alpha, 5 \alpha-\mathrm{LNG})$, as assessed by staining of osteoblasts fixed to plates, with a saturated Alizarin red-S solution. Neonatal rat osteoblastic cells were incubated with a single dose $(50 \mathrm{nM})$ of each steroid, for 15 consecutive days, using vehicle $(\mathrm{V})$ as control. Parallel incubations with NET or LNG were carried out in the presence of $75 \mu \mathrm{M}$ finasteride $(\mathrm{F})$, an inhibitor of $5 \alpha$-steroid reductases. The stereoscopic micrographs (magnification $\times 120)$ of a representative sample show the steroid-induced mineral deposition images, as well as the effect of $F$ on cells incubated with the corresponding unmodified synthetic progestin. The scale bar $(0-200 \mu \mathrm{m})$ is shown in the vehicle picture. For details refer text.

their parent compounds. The $3 \alpha, 5 \alpha$-derivatives of the synthetic progestins also induced a significant increase in osteoblast AP activity and OC content, though with lower potency than that of their $3 \beta$ epimers. The effects of NET and LNG on osteoblast differentiation were abolished by the addition of finasteride, a steroidal inhibitor of $5 \alpha$-steroid reductases, strongly suggesting that the effects of 19-norprogestins on cell differentiation were mediated by their A-ring reduced metabolic conversion products.

The results of osteoblast mineralization studies revealed that $\mathrm{E}_{2}$ was the more potent steroid to induce an increase in cell cultures calcium content, as previously demonstrated by $\mathrm{Qu}$ et al. (1998), while P was completely ineffective. In contrast, synthetic 19-norprogestins and their derivatives exhibited a clear-cut estrogen-like mineralization effect on osteoblasts.
The most relevant finding was that the $3 \beta, 5 \alpha-$ and $3 \alpha, 5 \alpha-$ reduced NET derivatives stimulated an increase in cell calcium accumulation, with a potency comparable with that of $\mathrm{E}_{2}$. The A-ring reduced derivatives of LNG also induce cell calcium increase, yet with lower potency. The effect of $\mathrm{E}_{2}$, synthetic progestins, and their derivatives on mineral deposition was even more evident when Alizarin red-S was used to visualize calcium deposits in osteoblast cultures. The microstereoscopic images of stained osteoblast cultures exposed to steroids correlate with the data of cell calcium content. The most potent inductors of calcium deposition were $\mathrm{E}_{2}$ and the $3 \beta, 5 \alpha$-reduced NET and LNG derivatives. The unmodified progestins and their $3 \alpha, 5 \alpha$-reduced derivatives also induced osteoblast mineralization, though with lower potency, while $\mathrm{P}$ was ineffective. Interestingly, 
finasteride was able to significantly diminish the formation of calcium deposits in osteoblast cultures induced by unmodified NET and LNG, furnishing additional support to the concept that the effects of 19-norprogestins on osteoblasts differentiation are exerted through their non-phenolic reduced metabolites. Presence of androgen and progestin metabolizing enzymes has been demonstrated in bone cells; thus, the activity of $5 \alpha$-steroid reductase in human osteoblasts has been documented (Shimodaira et al. 1996) and Issa et al. (2002) have reported the expression of types 1 and 2 of the steroid $5 \alpha$-reductase genes in human osteoblast-like cells. Vittek et al. (1974) reported the presence of $3 \alpha$, but not $3 \beta$, hydroxysteroid dehydrogenase in rat mandibular bone, and recent studies in our laboratory, using a reverse isotope dilution technique, have shown the presence of $3 \alpha-$ and $3 \beta$ hydroxysteroid dehydrogenases, members of the aldo-keto reductases superfamily, in cultured neonatal rat osteoblasts (unpublished results).

The overall results are consistent with the previous reports from our group, demonstrating that diverse estrogen-agonistic effects of NET and LNG are mediated by their non-phenolic A-ring reduced derivatives (Vilchis et al. 1986, Moralí et al. 1990, Santillán et al. 2001), and are in line with the concept that 19-norprogestins are effective agents in bone remodeling, while MPA does not, as demonstrated in controlled clinical trials (Liu \& Muse 2005). Furthermore, using co-transfected cell expression systems, we have shown that non-phenolic reduced metabolites of 19-norprogestins are able to transactivate estrogen-dependent genes mediated through human ER $\alpha$, but not through ER $\beta$ (Larrea et al. 2001, García-Becerra et al. 2002), behaving as selective $\mathrm{ER} \alpha$ modulators, with ligand-receptor structural and functional responses similar to those induced with naturally occurring $\mathrm{E}_{2}$ (García-Becerra et al. 2006). Additional studies on the effects of progestin reduced derivatives on breast tissue are required, particularly since an overexpression of the $5 \alpha$-steroid reductase type 1 gene has been reported in breast cancer tumors and cells (Suzuki et al. 2001, Wiebe \& Lewis 2003, Pérez-Palacios et al. 2006).

The data presented herein provide new insights to understand the underlying molecular mechanisms at the genomic level involved in the estrogenic effects on osteoblastic cells induced by synthetic 19-norprogestins, which are widely used in the prevention and treatment of bone loss in postmenopausal women, and also disclose alternate avenues of approach in hormone replacement therapy research.

\section{Acknowledgements}

The authors wish to thank Gerardo Arrellín, Georgina Díaz Herrera, Roberto Chavira Ramírez, Arturo Luna, and Ms Beatriz Alarcón for their expert assistance. This study was partially supported by grants from the World Health Organization, Special Programme of Human Reproduction, Geneva, Switzerland; Universidad Nacional Autónoma de
México, Secretaría de Desarrollo Institucional, Programa Transdisciplinario en Investigación y Desarrollo para Facultades y Escuelas (Macroproyecto SDI.PTID-05-3); Consejo Nacional de Ciencia y Tecnología grants $125818 \mathrm{~N}$ (GP-P, JE) and $42568-\mathrm{Q}$ (JC-M) and grants IN200205 (JC-M) and IN202102-3 (GP-P) from PAPIIT, DGAPA, UNAM, Mexico City, Mexico. The authors declare that there is no conflict of interest that would prejudice the impartiality of this scientific work.

\section{References}

Abdalla HI, Hart DM, Lindsay R, Leggate I \& Hooke A 1985 Prevention of bone mineral loss in postmenopausal women by norethisterone. Obstetrics and Gynecology 66 789-792.

Arzate H, Alvarez-Pérez MA, Aguilar-Mendoza ME \& Alvarez-Fregoso O 1998 Human cementum tumor cells have different features from human osteoblastic cells in vitro. Journal of Periodontal Research 33 249-258.

Bain SD, Lydon JP, Tibbetts T, Strachan MJ, Puerner DA \& O'Malley BW 1997 Mice lacking functional progesterone receptors have no apparent alterations in peak bone mass or bone histomorphometry. Journal of Bone and Mineral Research 12 S461 (Abstract S432).

Bradford MM 1976 A rapid and sensitive method for the quantitation of microgram quantities of protein utilizing the principle of protein-dye binding. Analytical Biochemistry 72 248-254.

Canalis E \& Raisz LG 1978 Effect of sex steroids on bone collagen synthesis in vitro. Calcified Tissue Research 25 105-110.

Chávez BA, Vilchis F, Pérez AE, García GA, Grillasca I \& Pérez-Palacios G 1985 Stereospecificity of the intracellular binding of norethisterone and its A-ring reduced metabolites. Journal of Steroid Biochemistry 22 121-126.

Christiansen C \& Riis BJ 1990 17 $\beta$-estradiol and continuous norethisterone: a unique treatment for established osteoporosis in elderly women. Journal of Clinical Endocrinology and Metabolism 71 836-841.

Ciriza I, Carrero P, Frye CA \& Garcia-Segura LM 2006 Reduced metabolites mediate neuroprotective effects of progesterone in the adult rat hippocampus. The synthetic progestin medroxyprogesterone acetate (Provera) is not neuroprotective. Journal of Neurobiology 66 916-928.

Costa Paiva L, Pinto-Neto AM \& Faundes A 1998 Bone density among longterm users of medroxyprogesterone acetate as a contraceptive. Contraception 58 351-355.

Di X, Li Y, Zhang C, Jiang J \& Gu S 1999 Effects of levonorgestrel-releasing subdermal contraceptive implants on bone density and bone metabolism. Contraception 60 161-166.

Gallagher JC, Kable WT \& Goldgar D 1991 Effect of progestin therapy on cortical and trabecular bone: comparison with estrogen. American Journal of Medicine 90 171-178.

García-Becerra R, Borja-Cacho E, Cooney AJ, Jackson KJ, Lemus AE, PérezPalacios G \& Larrea F 2002 The intrinsic transcriptional estrogenic activity of a non-phenolic derivative of levonorgestrel is mediated via the estrogen receptor- $\alpha$. Journal of Steroid Biochemistry and Molecular Biology 82 333-341.

García-Becerra R, Borja-Cacho E, Cooney AJ, Smith CL, Lemus AE, Pérez-Palacios G \& Larrea F 2006 Synthetic 19-nortestosterone derivatives as estrogen receptor alpha subtype-selective ligands induce similar receptor conformational changes and steroid receptor coactivator recruitment than natural estrogens. Journal of Steroid Biochemistry and Molecular Biology 99 108-114.

Ghoumari AM, Ibáñez C, El-Efr M, Leclerc P, Eychenne B, O’Malley BW, Baulieu EE \& Schumacher M 2003 Progesterone and its metabolitos increase myelin basic protein expresión in organotypic slice cultures of rat cerebellum. Journal of Neurochemistry 86 848-859.

Gual C, Morato T, Hayano M, Gut M \& Dorfman RI 1962 Biosynthesis of estrogens. Endocrinology 71 920-925.

Horowitz M, Wishart JM, Need AG, Morris HA \& Nordin BEC 1993 Effects of norethisterone on bone related biochemical variables and forearm bone mineral in post-menopausal osteoporosis. Clinical Endocrinology 39 649-655. 
Issa S, Schnabel D, Feix M, Wolf L, Schaefer H-E, Russell DW \& Schweikert H-U 2002 Human osteoblast-like cells express predominantly steroid $5 \alpha$ reductase type 1. Journal of Clinical Endocrinology and Metabolism 87 5401-5407.

Kalu DN, Salerno E, Liu CC, Echon R, Ray M, Garza-Zapata M \& Hollis BW 1991 A comparative study of the actions of tamoxifen, estrogen and progesterone in the ovariectomized rat. Bone and Mineral 15 109-124.

Kaplow LS 1955 A histochemical procedure for localizing and evaluating leukocyte alkaline phosphatase activity in smears of blood and marrow. Blood 10 1023-1027.

Khastgir G, Studd J, Holland N, Alaghband-Zadeh J, Fox S \& Chow J 2001 Anabolic effect of estrogen replacement on bone in postmenopausal women with osteoporosis: histomorphometric evidence in a longitudinal study. Journal of Clinical Endocrinology and Metabolism 86 289-295.

Labarca C \& Paigen K 1980 A simple, rapid, and sensitive DNA assay procedure. Analytical Biochemistry 102 344-352.

Larrea F, Vilchis F, Chávez B, Pérez AE, Garza-Flores J \& Pérez-Palacios G 1987 The metabolism of 19-nor contraceptive progestins modulates their biological activity at the neuroendocrine level. Journal of Steroid Biochemistry 27 657-663.

Larrea F, García-Becerra R, Lemus AE, García GA, Pérez-Palacios G, Jackson KJ, Coleman KM, Dace R, Smith CL \& Cooney AJ 2001 A-ring reduced metabolites of 19-nor synthetic progestins as subtype selective agonists for ER $\alpha$. Endocrinology 142 3791-3799.

Lau K-HW, Wang SP, Linkhart TA, Demarest KT \& Baylink DJ 1994 Picomolar norethindrone in vitro stimulates the cell proliferation and activity of a human osteosarcoma cell line and increases bone collagen synthesis without an effect on bone resorption. Journal of Bone and Mineral Research 9 695-703.

Lemus AE, Vilchis F, Damsky R, Chávez BA, García GA, Grillasca I \& PérezPalacios G 1992 Mechanism of action of levonorgestrel: in vitro metabolism and specific interactions with steroid receptors in target organs. Journal of Steroid Biochemistry and Molecular Biology 41 881-890.

Li X, Takahashi M, Kushida K, Shimizu S, Hoshino H, Suzuki M \& Inoue T 2000 The effects of nandrolone decanoate on bone mass and metabolism in ovariectomized rats with osteopenia. Journal of Bone and Mineral Metabolism 18 258-263.

Liu JH \& Muse KN 2005 The effects of progestins on bone density and bone metabolism in postmenopausal women: a randomized controlled trial. American Journal of Obstetrics and Gynecology 192 1316-1324.

Lowry OH, Roberts NR, Wu M-L, Hixon WS \& Crawford EJ 1954 The quantitative histochemistry of brain. II. Enzyme measurements. Journal of Biological Chemistry 207 19-37.

Montgomery DC 1991 Design and Analysis of Experiments. Belmont: Wiley, p 537.

Moralí G, Lemus AE, Oropeza MV, García GA \& Pérez-Palacios G 1990 Induction of male sexual behavior by norethisterone: role of its A-ring reduced metabolites. Pharmacology, Biochemistry and Behavior 37 477-484.

Nibbering PH, Van de Gevel JS \& Van Furth R 1990 A cell-ELISA for the quantification of adherent murine macrophages and the surface expression of antigens. Journal of Immunological Methods 131 25-32.

Passeri M, Pedrazzoni M, Pioli G, Butturini L, Ruys AHC \& Cortenraad MGG 1993 Effects of nandrolone decanoate on bone mass in established osteoporosis. Maturitas 17 211-219.

Pérez-Palacios G, Fernandez-Aparicio MA, Medina M, Zacarias-Villarreal J \& Ulloa-Aguirre A 1981 On the mechanism of action of progestins. Acta Endocrinologica 97 320-328.

Pérez-Palacios G, Santillán R, García-Becerra R, Borja-Cacho E, Larrea F, Damián-Matsumura P, González L \& Lemus AE 2006 Enhanced formation of non-phenolic androgen metabolitos with intrinsic oestrogen-like gene transactivation potency in human breast cancer cells: a distinctive metabolic pattern. Journal of Endocrinology 190 805-818.

Qu Q, Perälä-Heape M, Kapanen A, Dahllund J, Salo J, Väänänen HK \& Härkönen P 1998 Estrogen enhances differentiation of osteoblasts in mouse bone marrow culture. Bone 22 201-209.
Rhodes ME, McCormick CM \& Frye CA 2004 3 $\alpha, 5 \alpha$-THP mediates progestins' effects to protect against adrenalectomy-induced cell death in the dentate gyrus of female and male rats. Pharmacology, Biochemistry and Behavior 78 505-512.

Rickard DJ, Waters KM, Ruesink TJ, Khosla S, Katzenellenbogen JA, Katzenellenbogen BS, Riggs BL \& Spelsberg TC 2002 Estrogen receptor isoform-specific induction of progesterone receptors in human osteoblasts. Journal of Bone and Mineral Research 17 580-592.

Riggs BL, Khosla S \& Melton LJ III 2002 Sex steroids and the construction and conservation of the adult skeleton. Endocrine Reviews 23 279-302.

Riis BJ, Thomsen K, Strøm V \& Christiansen C 1987 The effect of percutaneous estradiol and natural progesterone on postmenopausal bone loss. American Journal of Obstetrics and Gynecology 156 61-65.

Riis BJ, Christiansen C, Johansen JS \& Jacobson J 1990 Is it possible to prevent bone loss in young women treated with luteinizing hormone-releasing hormone agonists? Journal of Clinical Endocrinology and Metabolism 70 920-924.

Santillán R, Pérez-Palacios G, Reyes M, Damián-Matsumura P, García GA, Grillasca I \& Lemus AE 2001 Assessment of the oestrogenic activity of the contraceptive progestin levonorgestrel and its non-phenolic metabolites. European Journal of Pharmacology 427 167-174.

Scheven BAA, Damen CA, Hamilton NJ, Verhaar HJ \& Duursma SA 1992 Stimulatory effects of estrogen and progesterone on proliferation and differentiation of normal human osteoblast-like cells in vitro. Biochemical and Biophysical Research Communications 186 54-60.

Scholes D, LaCroix AZ, Ichikawa LE, Barlow WE \& Ott SM 2002 Inyectable hormone contraception and bone density: results from a prospective study. Epidemiology 13 581-587.

Shimodaira K, Fujikawa H, Okura F, Shimizu Y, Saito H \& Yanaihara T 1996 Osteoblast cells (MG-63 and HOS) have aromatase and $5 \alpha$-reductase activities. Biochemistry and Molecular Biology International 39 109-116.

Stein GS, Lian JB \& Owen TA 1990 Relationship of cell growth to the regulation of tissue-specific gene expression during osteoblast differentiation. FASEB Journal 4 3111-3123.

Suzuki T, Darnel AD, Akahira J-I, Ariga N, Ogawa S, Kaneko C, Takeyama J, Moriya T \& Sasano H $20015 \boldsymbol{\alpha}$-Reductases in human breast carcinoma: possible modulator of in situ androgenic actions. Journal of Clinical Endocrinology and Metabolism 86 2250-2257.

Tremollieres FA, Strong DD, Baylink DJ \& Mohan S 1992 Progesterone and promegestone stimulate human bone cell proliferation and insulin-like growth factor-2 production. Acta Endocrinologica 126 329-337.

Vilchis F, Chávez B, Pérez AE, García GA, Angeles A \& Pérez-Palacios G 1986 Evidence that a non-aromatizable metabolite of norethisterone induces estrogen-dependent pituitary progestin receptors. Journal of Steroid Biochemistry 24 525-531.

Vittek J, Altman K, Gordon GG \& Southern AL 1974 The metabolism of $7 \alpha-{ }^{3} \mathrm{H}$-testosterone by rat mandibular bone. Endocrinolog $\gamma 94$ 325-329.

Wiebe JP \& Lewis MJ 2003 Activity and expression of progesterone metabolizing $5 \alpha$-reductase, $20 \alpha$-hydroxy steroid oxido reductases in tumorigenic (MCF-7, MDA-MB 231, T-471) and nontumorigenic (MCF10A) human breast cancer cells. BMC Cancer 3 1-15.

Yamamoto Y, Kurabayashi T, Tojo Y, Yahata T, Honda A, Tomita M \& Tanaka K 1998 Effects of progestins on the metabolism of cancellous bone in aged oophorectomized rats. Bone 22 533-537.

\section{Received in final form 14 March 2007 \\ Accepted 18 March 2007 \\ Made available online as an Accepted Preprint 23 March 2007}

